\title{
Mediating Role of Perceived Risk on Relationship Between Perception Towards Online Luxury Shopping and Online Purchase Intention: A Study with Reference to Young Professionals in India
}

\author{
Jithin Benedict ${ }^{1}$ and M. S. Raju ${ }^{2}$ \\ ${ }^{1}$ Research Scholar, ${ }^{2}$ Professor \& Director, SME \\ ${ }^{1 \& 2}$ Kerala University of Fisheries and Ocean Studies, Kerala, India \\ E-Mail: benedictjithin@gmail.com,msraju01@yahoo.com
}

\begin{abstract}
To many people, luxury products were once considered hard to access and a privilege to use. Luxury used to mean a product or service only accessible by a small group of people, a product or service that was scarce (Nueno \& Quelceh, 1998). However, luxury products have now become more affordable to more consumers, especially for consumers from the middle class who access more money than ever before (Hauck \& Stanforth, 2007). These "newcomers" do not fall into the traditional wealthy income segment; they start purchasing luxury at a younger age compared to their parents (Jay, 2012). In recent times, demand for luxury brands is spurred by digitalization. Digital platform are increasingly used by the retailers to provide ease of shopping and to extend their reachability among the customers. According to Assocham (2018) study the online luxury stores will see an influx of 44 billion dollars in 2019 and by 2020 the study foresees the market to get doubled. The study attempts to understand the relationship between perceptions of young working professionals of India towards personal luxury goods and their purchase intention. Further study delves to understand the mediating role of perceived risk of shopping luxury goods online. Structured questionnaire was framed and respondents of the age group 18 to 35 who has shopped luxury goods online were found out from online shopping sites, social media groups of online shoppers. From the analysis it has been deduced that perceived risk partially mediates the relationship between perception towards online luxury shopping and online purchase intention.
\end{abstract}

Keywords: Online Luxury Shopping, Indian Youth Luxury Shopping, Online Purchase Intention, Multiple Regression

\section{INTRODUCTION}

"Luxury is a necessity that begins where necessity ends." Gabrielle Bonheur Chanel

The association between human beings and luxury goes through millennia, and it was often reserved for the elite in society. The luxury industry sector is a very stimulating and interesting area. Researchers are struggling to find definitions of the term "luxury management" and as many authors suggest, principal marketing and brand management rules do not apply for a luxury strategy. Luxury as itself goes back to the beginning of mankind and has developed over centuries. During the last decades, the luxury sector has undergone a large change. However, with rapid globalization, purchasing luxury items has come within the grasp of an ordinary person (Hader, 2008; Eng and Bogaert, 2010; Brun and Castelli, 2013) throughout the world (Wong and Ahuvia, 1998). The "democratization of luxury" means that luxury goods or goods that resemble luxury goods are now available to an increased number of consumers (Okonkwo 2007, 226-227). It seems like the two concepts 'luxury' and 'e-business' are contradicting each other. While luxury is very exclusive and rare, the internet on the other hand is a mass medium characterized by its ubiquity (Laudon \& Traver, 2012). The growing number of upper middle class and their aspirations to climb up the consumption ladder is making the luxury marketers launch entry level luxury like apparel, accessories, watches and jewelry to help them ascend the ladder. The luxury group like LMVH, PPR and Richemont focus on the retail these high margin products as they are the first categories purchased by consumers on reaching their income threshold in order to become an active luxury consumer (Ortelli and D’Ath, 2013)

\section{INDIA'S GROWTH IN LUXURY SEGMENT}

Globally the market for luxury brands has grown rapidly over the past two decades. India's luxury market is set to grow to USD 30 billion from USD 23.8 billion by 2018 on back of growing exposure of international brands amongst Indian youth and higher purchasing power of the upper class in tier II and III cities (Assocham, 2018)

In past five years with the growth in global market, the luxury brands' market has increased by 31 percent where the market for the non-luxury brands has increased by 7 percent only (Tynan, 2018). The appetite for luxury brands is growing in the emerging economies of China, India, Asia, the Middle East and Latin America (Verdict, 2017; Chadha and Husband, 2016). Research reflects that Asian customers prize the perceived conspicuous value of goods (Cheah, I., Zainol, Z., \& Phau, I. (2016). Conceptualizing 'country-ofingredient-authenticity' of luxury brands. Journal of Business Research, 69(12), 5819-5826 (in \& Prendergast, 2000) making it easier for the luxury goods industry to be successful. The luxury market in India is growing and experts say, by 2015, a quarter of the luxury market will be between India and China. (Mint Luxury conference, 2017). 
As per LaxmanNarasimhan, Director, Mckinsey “The growth in India between 2018 and 2020 will become even larger as more people come into the consumption curve.

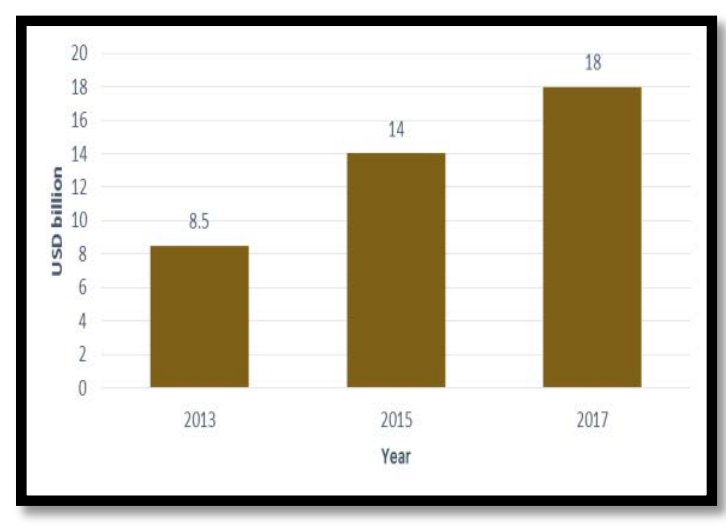

Fig. 1 Growth of Indian luxury market

As the Indian consumer gets more aware of the presence of luxury brands, these goods continue to register a strong growth in India and focus on the Indian consumer. Though Delhi and Mumbai find the biggest buyers of these brands, rapid urbanization has also revealed that the market is slowly penetrating into second and third-tier cities too. While Delhi tops the list of leading Indian cities followed by Mumbai, Bangalore, Chennai, Kolkata, Hyderabad and Pune follow next in terms of Tier II cities. (ASSOCHAM, KPMG). India's year on year growth figures in this sector is poised to register a healthy $25 \%$ increase. The number of Indians that featured on the Forbes Billionaires List in 2004 was 9. By the year 2013, this figure rose to 55 billionaires that accounted for a total net worth of $\$ 194$ billion. The number of millionaire households measured in terms of Rs. 250 million or $\$ 3.8$ million increased by $17 \%$ since 2014 with a greater demand in luxury goods.(PRNewswire, 2015) Billionaires apart, it was noticed that the Indian luxury landscape was experiencing strong evolutionary undercurrents that were redefining consumer profiles and strategies presently being used. New terminology defined this: "HENRY" was the term used to address, 'High Earnings Not Rich Yet' buyers that have become a new target segment for these brands.

\section{YOUNG CONSUMERS OF INDIA}

"Youth" means "every person between the ages of 15 and 35 years” (adopted from UNESCO, 2012). A significant percentage of youth population in India attains some sort of financial independence around the age of 25 years. The youth who are less than 24 years old mostly depend upon their parents for financial assistance. But the present youth segment of India, is unique in terms of its sheer size, consumption of products/services, intellectual ability, pester power, trend setting capability and positive attitude towards modern technology. Young generation of the current era considers shopping as an experience rather than a mere act of purchasing a product. Possessed with lesser commitments, the youth purchase or use products/ services at their will. Further, they are also capable of influencing the consumption at even household level. Hence, the marketers and retailers operating in the country have a daunting task ahead of them in targeting and tracking a unique set of young consumers for their products and services.

\section{PURPOSE OF THIS STUDY}

There is a dearth of literature in understanding the factors leading to perception towards online luxury shopping. The past studies were done in store purchase of luxury goods and sufficiently did not identify the difference it makes for online luxury purchase.

In India, young consumers are value seekers and have increasingly become brand conscious. New affluent is familiarized to the luxury world quickly and are willing to display their arrival. (Milano Fashion global summit, 2008) This makes personal luxury goods that include apparel/ accessories and watches/jewelry categories particularity relevant for the study as these categories are sensitive to social influence as a display of wealth. These product categories are the most preferred by this segment when they reach disposable income threshold to become a luxury customer. In an emerging country like India they have considerable relevance. (Ortelli and D’Ath, 2013)

India is an upcoming online market. The total number of people purchasing goods via E commerce is 1.77 billion, which is 23 percent of Indian population. Previous studies have figured out perceived risk as a major factor when it comes to online shopping. The thrust of risk increases when the product shopped is of expensive in nature.

The present research is to understand the relationship between perceptions of young Indian working professionals towards personal luxury goods and their purchase intention. Further study is to understand the mediating role of perceived risk of shopping luxury goods online.

\section{LITERATURE REVIEW}

Various studies in the past have developed conceptual models based on perception dimension of luxury products, Framework developed by Vigneron and Johnson (1999) suggests that luxury consumption is motivated by social influences namely, 'veblen, snob and bandwagon effect' and personal influences, namely "hedonic and perfectionism effects”

Various studies in the past have developed conceptual models bsed on value perception dimentions for luxury products (Vigneron \& Johnson, 1999, 2004; Wiedmann et al., 2007; Berthon et al., 2009; smith and colgate, 2007).

The following factors of luxury perceptions are adopted from Vigneron \& Johnson, Wiedmannet al., and the factors of online shopping are also considered. 
A. Price Consciousness $(\operatorname{PrC})$ : High price of luxury is particularly perceived as an indicator of high quality, exclusivity, as well as status and prestige - high price even making certain luxury products or services more desirable to certain consumers (Tellis \& Gaeth, 1990; Groth \& McDaniel, 1993; Lichtenstein et al., 1993; Vigneron \& Johnson, 1994 \& 1999). Also when perceived price is higher than the actual one by, for example, having additional costs of time, energy, and such, additional value can be created (Dubois et al., 2001; Kapferer \& Bastien, 2009). But the masstige consumers are price conscious. They search the different websites for comparison and look for offers and price drops. The surge in sales of personal luxury goods during amazon and filpkart sales of 2018 October substantiates it.

B. Perceived Ease of Use (PEoU): Perceived Ease of use was defined as the degree to which an individual believes that by using a particular technology would be free of effort (Davis, 1989). It has strong influence on intention to technology acceptance. Ease of use should be based on both the product's function and the consumers' needs. Consumers expect especially luxury products to function well and for a long time, and to look good, associating usability with the quality of use. The core benefit or a product or a service should satisfy consumer needs. (Wiedmann et al., 2007; Ciornea et al., 2011)

C. Perceived Quality (PQ): Perceived quality is a critical element for consumer decision making; consequently, consumers will compare the quality of alternatives with regard to price within a category (Jin and Yong, 2005). High quality is seen as one of the main fundamental characters of luxury and consumers expect luxury brands to offer excellent quality and performance, compared to non luxury brands, thus consumers perceive luxury brands to be closely associated with superior quality and so they perceive more value from it (Garfein, 1989; Dubois \& Laurent, 1994; Aaker, 1997; Dubois et al., 2001; Vigneron \& Johnson, 2004; Kapferer \& Bastien, 2009).According to Davis et al., (2003), perceived quality is directly related to the reputation of the firm that manufactures the product. However, National Quality Research Center or NQRC (1995) defined perceived quality as the degree to which a product or service provides key customer requirements (customization) and how reliably these requirements are delivered (reliability). Whereas Aaker (1991) and Zeithaml (1988a) said that perceived quality is not the actual quality of the brands or products, rather, it is the consumers' judgment about an entity's or a service's overall excellence or superiority.

D. Perceived Uniqueness (PU): Exclusivity offered by luxury brands are often well used in marketing promotion and the concept is also well documented (Pantaliz, 1995). Product uniqueness is one of the critical features in developing a brand's characteristics and the image sending to the consumers. The rarer or more unique a brand is, the more value it symbolizes, at least in consumer's perception
(Sun, 2011). Therefore luxury brands usually try to control their unique experience through high-end department stores, specialty stores and personally owned boutiques (Lipps, 2009). Consumers need for uniqueness is defined as "an individual's pursuit of differentness relative to others that is achieved though the acquisition, utilization and disposition of consumer goods for the purpose of developing and enhancing one's personal and social identity" (Tepper ,Bearden and Hunter, 2001). Globally, need for uniqueness has positive influence on luxury consumption) O'cass and McEsen, 2004; Park, Rabolt and Jeon, 2008).

E. Perceived Hedonism (PH): Luxury products and services often convey consumers an emotional value and intrinsic enjoyment (Dubois \& Laurent, 1994; Vickers \&Renand, 2003; Kapferer \& Bastien, 2009). Consuming luxury products and services is likely to provide the subjective intangible benefit of emotional responses, such as sensory pleasure and gratification, aesthetic beauty, or excitement. However, hedonism is not only attached to simple pleasures or senses, but also retrieves pleasure from complex emotions that supplement different experiences. (Vigneron \& Johnson, 2004; Ciornea et al., 2011) A consumer that is focused on the hedonic value aspect is less or not at all susceptible to interpersonal influence as their main motivation for consuming luxury is more emotional than functional benefit oriented and they rather want to get relaxation, self-respect, and inner self-congruency from the luxury purchased and consumed (Vigneron \& Johnson, 2004; Tsai, 2005). For these consumers luxury consumption arouses feelings and affective states, received from personal rewards and fulfillment of purchasing and consuming luxury brands (Sheth et al., 1991; Westbrook \& Oliver, 1991).

F. Perceived Brand Consciousness (PBC): It is defined as "the psychological preference towards famous brand name goods” (Zhang and Kim, 2013). Brand consciousness is a major influencing factor in consumption (La Chanc et al., 2003). Research conducted in India shows that the brand consciousness plays a positive role in consumption.

G. Perceived Conspicuousness (PC): Bearden and Etzel (1982) showed that when a high level of reference group influence is present, it is more likely to those public luxuries will be consumed, the assumption being that the consumer wishes to send a positive signal about their status to significant others. Veblen (1899) theory of conspicuous consumption is also premised on the notion that when individuals consume luxury goods and services conspicuously they are sending a signal to others about relative status in society. Mason (1981) views satisfaction resulting from conspicuous consumption as being consequence of audience reaction to the wealth displayed by purchase and not from the actual qualities of the good or service.

H. Perceived Prestige (PP): The pursuit of status through consumption appears to be a phenomenon that is common to 
human society, across time and across cultures. Status consumption and conspicuous consumption are frequently identified in the literature as being essentially the same concept. O’Cass and McEwen (2004) argue that such as definition that defines one concept in terms of another is incorrect. Because of its value, the possession of luxury goods normally signifies the owner's economic status. Dubois and Duquesne (1993) studied that the reason of consuming luxury goods is primarily for their symbolic value.

I. Perceived Risk (PR): The concept of perceived risk was introduced by Tzenget al., (2005), he proposes that risk be conceived in terms of the uncertainty and consequences associated with consumer actions, the result of which may or may not be pleasant. Perceived risk is defined as the uncertainty that consumers face when they cannot foresee the consequences of their purchased decision. This definition highlights two relevant dimension of perceived risk: uncertainty and consequences. When a consumer make a purchase decision, 'risk' implies 'great consequences of making a mistake' and 'degree of inconvenience of making a mistake' (Batra and Sinha, 2000; Bettman, 1979; Schiffman, 1972; Cox, 1967; Havlena and De Sarbo, 1991; Peter and Ryan, 1976). According to Zeithaml and Bitner (2003), perceived risk will typically influence early stage of consumer buying process. Beside that, Dowling and Staelin (1994) define risk as a consumer perception of uncertainty and adverse consequences of engaging in an activity

\section{PROPOSED MODEL}

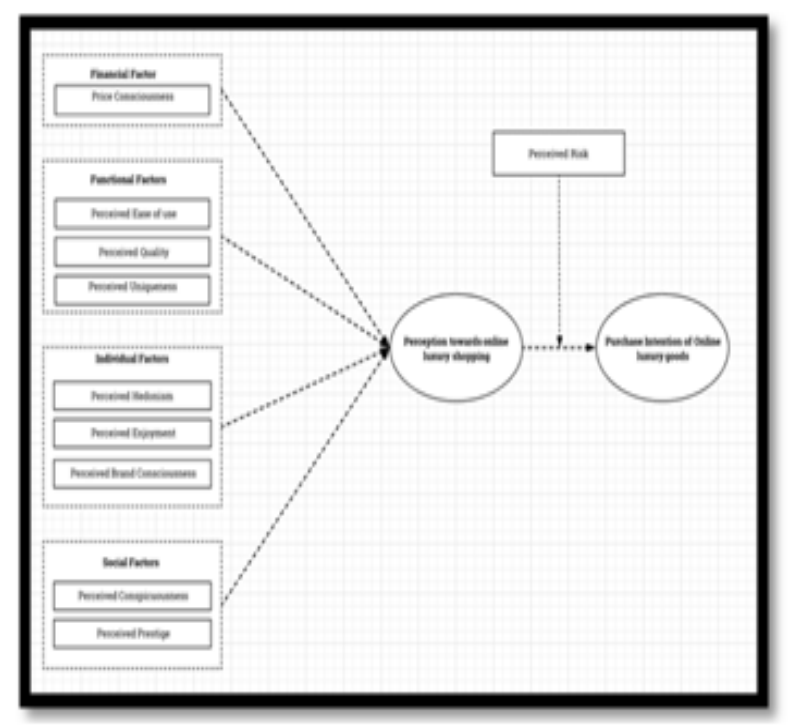

Fig.2 Proposed Model

\section{RESEARCH METHODOLOGY}

Initially, literature review was conducted to find out various financial, functional, individual and social factors affecting the perception towards online luxury shopping. The scale items were identified from the literature. The scale items were validated during questionnaire designing. Structured questionnaire was framed and respondents of the age group 18 to 35 who has shopped luxury goods online were found out from online shopping sites, social media groups of online shoppers, courier services while they deliver personal luxury goods. Out of which 278 were retained after filtering the initial set of questions.

In order to test the relationship between Perception towards Online Luxury Shopping and Online Purchase Intention and the mediating role of perceived risk multiple regression analysis was used. Multiple regression allows us to examine how multiple independent variable are related to a dependent variable.

\section{RESULTSAND DISCUSSIONS}

Perceived Risk mediates the relationship between Perception towards Online Luxury Shopping and Online Purchase Intention.

A.Step-I: regress online purchase intention $(d v)$ on perception towards online luxury (iv)

TABLE I REGRESSION OF ONLINE PURCHASE INTENTION ON PERCEPTION TOWARDS ONLINE LUXURY

\begin{tabular}{|l|c|c|c|c|c|}
\hline & \multicolumn{2}{|c|}{$\begin{array}{c}\text { Unstandardized } \\
\text { Coefficients }\end{array}$} & \multirow{2}{*}{$\begin{array}{c}\text { Standardized } \\
\text { Beta }\end{array}$} & $\begin{array}{c}\text { T } \\
\text { value }\end{array}$ & $\begin{array}{c}\text { P } \\
\text { value }\end{array}$ \\
\cline { 2 - 3 } & Beta & SE & & 3.092 & 0.002 \\
\hline Constant & 4.192 & 1.356 & & & \\
\hline $\begin{array}{l}\text { Perception } \\
\text { towards } \\
\begin{array}{l}\text { Online } \\
\text { Luxury } \\
\text { Shopping }\end{array}\end{array}$ & 0.071 & 0.012 & 0.445 & 6.052 & 0.000 \\
\hline
\end{tabular}

As the p-value corresponding to perception towards online luxury shopping is less than the significance level 0.01 , perception towards online luxury shopping has a significant positive impact on online purchase intention.

\section{B. Step-II: regress perceived risk (mediator) on perception towards online luxury (iv)}

TABLE II: REGRESSION OF PERCEIVED RISK ON PERCEPTION TOWARDS ONLINE LUXURY

\begin{tabular}{|l|c|c|c|c|c|}
\hline & \multicolumn{2}{|c|}{$\begin{array}{c}\text { Unstandardized } \\
\text { Coefficients }\end{array}$} & $\begin{array}{c}\text { Standardized } \\
\text { Beta }\end{array}$ & $\begin{array}{c}\text { T } \\
\text { value }\end{array}$ & $\begin{array}{c}\text { P } \\
\text { value }\end{array}$ \\
\cline { 2 - 3 } & Beta & SE & & 3.753 & 0.000 \\
\hline Constant & 6.538 & 1.742 & & 3.995 & 0.000 \\
\hline $\begin{array}{l}\text { Perception } \\
\text { towards } \\
\begin{array}{l}\text { Online } \\
\text { Luxury } \\
\text { Shopping }\end{array}\end{array}$ & 0.060 & 0.015 & 0.312 & & \\
\hline
\end{tabular}

As the p-value corresponding to perception towards online luxury shopping is less than the significance level 0.01 , perception towards online luxury shopping has a significant positive impact on perceived risk. 
C. Step-III: Regress Online Purchase Intention (Dv) On Perceived Risk (Mediator) And Perception Towards Online Luxury (iv)

TABLE III: Regression of ONLINE PuRchase INTENTION ON PERCEIVED RISK AND PERCEPTION TOWARDS ONLINE LUXURY

\begin{tabular}{|l|c|c|c|c|c|}
\hline & \multicolumn{2}{|c|}{$\begin{array}{c}\text { Unstandardized } \\
\text { Coefficients }\end{array}$} & $\begin{array}{c}\text { Standardized } \\
\text { Beta }\end{array}$ & $\begin{array}{c}\text { T } \\
\text { value }\end{array}$ & $\begin{array}{c}\text { P } \\
\text { value }\end{array}$ \\
\cline { 2 - 3 } & Beta & SE & & 2.234 & 0.027 \\
\hline Constant & 3.107 & 1.391 & & & \\
\hline $\begin{array}{l}\text { Perception } \\
\text { towards } \\
\text { Online } \\
\begin{array}{l}\text { Luxury } \\
\text { Shopping }\end{array}\end{array}$ & 0.061 & 0.012 & 0.383 & 5.040 & 0.000 \\
\hline $\begin{array}{l}\text { Perceived } \\
\text { Risk }\end{array}$ & 0.166 & 0.063 & 0.201 & 2.646 & 0.009 \\
\hline
\end{tabular}

Here, the p-values corresponding to perception towards online luxury shopping and perceived risk are less than the significance level 0.01 ; perception towards online luxury shopping and perceived risk have a significant positive impact on online purchase intention. As the beta coefficient is reduced from step-I to step-III (0.071 to 0.061), perceived risk partially mediates the relationship between perception towards online luxury shopping and online purchase intention.

The Sobel test also confirms the result with $\mathrm{p}=0.028(\mathrm{Z}=$ 2.200 with $\mathrm{SE}=0.005$ ).

\section{FINDINGS, IMPLICATION AND CONCLUSION}

Based on the findings it is evident that Perception towards Online Luxury Shopping has a positive relationship with Online Purchase Intention, where by luxury marketers who cater to young online luxury consumers need to consider the antecedents of Perception towards Online Luxury Shopping like perceived prestige, perceived uniqueness, perceived Hedonism, perceived Quality for creating a conducive atmosphere for consumers to purchase personal luxury goods online.

Study reveals that perceived risk partially mediates the relationship between perception towards online luxury shopping and online purchase intention. This throws light on the fact that Indian consumers have apprehensions when it comes to buying luxury goods online, of the fact that they are investing huge money at stake and with the quality attributes of the product. Luxury brand companies should closely work with consumers to reduce the risk factors of monetary transactions, counterfeit products and post purchase dissonance for more acceptability of online luxury shopping.

Findings revealed that perceived prestige, perceived uniqueness, perceived Hedonism, perceived Quality had a positive and significant relationship with perception towards online luxury shopping. These studies are in line with previous studies (Vigeneron and Johnson, 2004; Tsai, 2005). However, Perceived conspicuousness was found to have negative impact on perception towards online luxury shopping which contradicts observations of earlier researchers (Eng and Bogeart, 2010; Zhan and He, 2012). This further throws light to the fact that Indian luxury consumers are gradually maturing. Traditionally they were buying just to "impress others" but now that are motivated to buy luxury brands online to attain inner- satisfaction, unique experience and excellent quality. Therefore the findings of this study will help online luxury brand companies to closely look at the factors that drive Indian consumers to buy exorbitantly priced luxury brands and then accordingly design their penetration and expansion strategies to gain foothold in the growing Indian market.

\section{DIRECTIONS FOR FUTURE RESEARCH}

There are a few limitations for this study which provide a path forward for future research work. First, the score of this study is confined to personal luxury goods, Second, this research is restricted to only working youth. Third, the results of this study showed significant but negative relationship between Perception towards Online Luxury Shopping and conspicuous value which is contradictory to various studies conducted in the past (Wong and Ahuvia, 1998; Vigneron and Johnson, 1999). Therefore, the findings of this study can be further validated by future studies in this domain.

\section{REFERENCES}

[1] Aaker, D. (1991), Managing Brand Equity: Capitalizing on the Value of a Brand Name. New York: Free Press.

[2] Arnould, E. J., \& Price, L. L. (1993). River Magic: Extraordinary Experience and the Extended Service Encounter. Journal of Consumer Research, 20(1), 24-45.

[3] Bhattacharya, C. B., \& Sen, S. (2003). Consumer-Company Identification: A Framework for Understanding Consumers' Relationships with Companies. Journal of Marketing, 67(2), 76-88.

[4] Birtwistle, G. and Tsim, C. (2005), Consumer purchasing behaviour: an investigation of the UK mature women's clothing market. Journal of Consumer Behaviour, 4, 453-464. doi: 10.1002/cb.31

[5] Chang, P., \& Chieng, M. (2006). Building Consumer - Brand Relationship: A Cross-Cultural Experiential View. Psychology \& Marketing, 23(11), 927-959. doi:10.1002/mar

[6] Chadha, R. and Husband, P. (2007), The Cult of Luxury Brand, Inside Asia's Love Affair with Luxury, London: Nicholas Brealey International.

[7] Dubois, B., \& Duquesne, P. (1993). The Market for Luxury Goods: Income versus Culture. European Journal of Marketing, 27(1), 3544.

[8] Kapferer, J. N., \&Bastien, V. (2012). The Luxury Strategy (2nd editio.). Kogan Page, London.

[9] Kapferer, Jean-Noël \&Bastien, Vincent (2009). The luxury strategy: breaking the rules of marketing to build luxury brands. London; Philadelphia: Kogan Page.

[10] Kim, A. J., \&Ko, E. (2010). Impacts of Luxury Fashion Brand's Social Media Marketing on Customer Relationship and Purchase Intention. Journal of Global Fashion Marketing, 1(3), 164-171. doi:10.1080/20932685.2010.10593068

[11] Nueno, J.L. \&Quelch, J.A. (1998) The Mass Marketing of Luxury. Business Horizons, 41(6), 61-69.

[12] Okonkwo, U. (2009). Sustaining the luxury brand on the Internet Journal of Brand Management, 16(5-6), 302-310. doi:10.1057/bm.2009.2 
Mediating Role of Perceived Risk on Relationship Between Perception Towards Online Luxury Shopping and

Online Purchase Intention: A Study with Reference to Young Professionals in India

[13] Okonkwo, U. (2009): Sustaining the Luxury Brand on the Internet, in: Journal of Brand Management, 16, (5/6), 302-310.

[14] Oliver, R. L. (1999). Whence Consumer Loyalty? Journal of Marketing, 63(4), 33. doi:10.23.15/1252099

[15] Phau, I. and Prendergast, G., 2000. Consuming luxury brands: The relevance of the rarity principle. Journal of Brand Management, 8 (2), 122-138.

[16] Riley, Francesca Dall'Olmo\&Lacroix, Caroline (2003). Luxury branding on the internet: lost opportunity or impossibility? Marketing Intelligence \& Planning; ABI/INFORM Global, 21(2), 96104.

[17] Sung, Y., \& Kim, J. (2010). Effects of brand personality on brand trust and brand affect. Psychology and Marketing, 27(7), 639-661. doi:10.1002/mar.20349

[18] Truong, Y. (2009). New luxury brand positioning and the emergence of masstige brands. Journal of Brand Management, 16(5/6), 375-382.

[19] Truong, Y., Simmons, G., McColl, R., \& Kitchen, P. J. (2008). Status and Conspicuousness - Are They Related? Strategic Marketing Implications for Luxury Brands. Journal of Strategic Marketing, 16(3), 189-203.

[20] Vickers, J. S., \&Renand, F. (2003). The Marketing of Luxury Goods: An exploratory study - three conceptual dimensions. The Marketing Review, 3(4), 459-478.

[21] Vigneron, F., \& Johnson, L. W. (1999). A Review and a Conceptual Framework of Prestige-Seeking Consumer Behavior. Academy of Marketing Science Review, 1(1), 1-15.
[22] Wee, C.H., Tan, S.J \&Cheok, K.H (1995) "Non-price determinants of intention to purchase counterfeit goods - An Exploratory Study" International Marketing Review 12(6), 19-46.

[23] Williams, M. (2001). In Whom We Trust: Group Membership As an Affective Context for Trust Development. Academy of Management Review, 26(3), 377-396. doi:10.5465/AMR.2001.4845794

[24] Wong, A.C.Y. and Zaichkowsky, J.L. 1999, Understanding Luxury Brands in Hong Kong, European Advances in Consumer Research, 4, 310-16.

[25] Wiedmann, K. P., Hennigs, N., \&Siebels, A. (2009). Value-based segmentation of luxury consumption behavior. Psychology and Marketing, 26, 625-651

[26] Zhou, Z., Zhang, Q., Su, C., \& Zhou, N. (2012). How do brand communities generate brand relationships? Intermediate mechanisms. Journal of Business Research, 65(7), 890-895. doi:10.1016/j. jbusres.2011.06.034

[27] Website: www.burberry.com. [Online] Available: http://www.bur berry. Com/en-row/\#/en-row/aboutburberry/history, Retrieved: 201601-16

[28] Website: www.gucci.com. [Online] Available: http://www.gucci. com/ uk/uk-english/about-gucci/gucci-group.html, Retrieved: 201004-21

[29] Website:www.louisvuitton.com. [Online] Available: http://www.louis vuitton.com/uk/flash/index.jsp?direct1=home_entry_gb, Retrieved: 2015-09-21. 